\title{
Tendencies and perspectives of central alpha2-adrenomimetic application in medico-biological research
}

Nikolay G. Vengerovich, Igor M. Ivanov, Yulia A. Proshina State Scientific Test Research Institute of Military Medicine, Ministry of Defense of the Russian Federation, St.-Petersburg, Russia

\begin{abstract}
The pharmacodynamic effects of the administration of a2-adrenergic agonists both in a monovariant and in combination with drugs of other pharmacological groups are considered. Based on analysis of safety nonclinical studies the characteristics of main physiological effects of a2-adrenergic receptors as well as physiological effects of a2-agonists on various organs and systems are presented. For the determination of tendencies and directions in research of central a2-AM (dexmedetomidine) the analysis of bibliographical data, accumulated and extracted from Medline database with 5 year time-filter (VOSviewer, 1.6.11 version) has been carried out. For the further research of central a2-adrenomimetics and their application in clinical practice the following perspective directions have been determined: the study of effects and mechanisms of cytoprotectant and antioxidant action, the study of the use of drugs in a monovariant and in combinations for the development of analgesic drugs, anesthesia and development of combined formulations with a delayed release of antagonists designed to mitigate side effects.
\end{abstract}

\section{KEYWORDS}

Alpha2-adrenomimetics, a2-agonists, dexmedetomidine, combinations, antioxidant, cytoprotection, lipid peroxidation.

\section{Тенденции и перспективы применения центральных альфа2-адреномиметиков в медико- биологических исследованиях (обзор литературы)}

Н.Г. Венгерович, И.М. Иванов, Ю.А. Прошина

Государственный научно-исследовательский испытательный институт военной медицины Министерства обороны Российской Федерации, Санкт-Петербург, Россия

\begin{abstract}
PEЗЮME
Рассмотрены фармакодинамические эффекты при введении а2-адреномиметиков как в моноварианте, так и в комбинации с препаратами других фармакологических групп. На основе анализа доклинических исследований безопасности представлена характеристика основных физиологических эффектов а2-адренорецепторов, а также физиологических эффектов при воздействии а2-агонистов на различные органы и системы. Для определения тенденций и направлений исследования центральных а2-АМ (по дексмедетомидину) выполнен анализ библиографических данных, отобранных в базе MEDLINE с временным фильтром "5 лет». (VOSviewer версии 1.6.11). В качестве наиболее перспективных направлений для дальнейших исследований центральных а2 адреномиметиков и их применения в клинической практике определены изучение эффектов и механизмов цитопротекторного и антиоксидантного действия, исследование применения лекарственных средств в моноварианте и в комбинациях для разработки анальгетических препаратов, анестезии и создание комбинированных рецептур с замедленным высвобождением антагонистов с целью нивелирования побочных эффектов.
\end{abstract}

\section{КЛЮЧЕВЫЕ СЛОВА}

Альфа2-адреномиметики, а2-агонисты, дексмедетомидин, комбинации, антиоксидант, цитопротекция, перекисное окисление липидов. 


\section{INTRODUCTION}

Medetomidine is a potent and highly specific alpha2adrenergic receptor agonist ( $\alpha_{2}-\mathrm{AR}$ ), is registered in 34 countries and is widely used abroad. In medico-biological research its dextrorotatory isomer - dexmedetomine is broadly used [1]. According to its chemical properties, medetomidine is a lipophilic compound that is rapidly and completelyabsorbed whenadministered intramuscularly. The half-absorption period is approximately 7 minutes; the peak concentration in plasma is reached in 30 minutes [2]. Dexmedetomidine is a racemic mixture of two stereoisomers, dextro- and levomedetomidine. The dextrorotatory isomer is an active principle of the drug, levorotatory is practically depleted of any pharmacological activity and induces moderate sedation and analgesia only when administered in high doses [3]. The drug can be administered intravenously (iv), intramuscularly (im) and subcutaneously (sc), but the last route of administration is inferior to others in completeness and intensity of sedation [4].

The pharmacological effects of dexmedetomidine, which determine its field of application in medico-biological research, are characteristic of alphaz-adrenergic agonists ( $\left.\alpha_{2}-\mathrm{AM}\right)$ and include deep sedation, analgesia, muscle relaxation, anxiolytic effect, the reduction of need for iv and inhalation anesthetics.

Within the pharmacological group, dexmedetomidine is one of the most novel and selective agents, however, it is not devoid of undesirable effects from the cardiovascular system (bradycardia, arrhythmia, hypo-andhypertension, decreased cardiac output), which are observed with the introduction of a2-AM of the first generation (xylazine). This causes some caution among clinicians about the application of dexmedetomidine in premedication and as a sedative agent, especially in a monovariant.

Nevertheless the quantity of publications on this drug is still increasing from 2004 (Fig. 1), and overall number of nonclinical and clinical research in 2018 was 142 and 118 respectively.

The decrease of amount of nonclinical and clinical research of dexmedetomidine in 2019 in the background of preservation of considerable volume of experimental research allows to admit widening of application evidence of a particular drug and representatives of a pharmaceutical group in general.

Elaboration of experimental data of a2-AM pharmacodynamics as well as the analysis of directions of nonclinical and clinical studies will allow to expand the understanding of possibilities for application of drugs, belonging to this pharmacological group, in clinical practice both in a monovariant and as a part of combined formulations.

\section{Physiological effects of alpha2-adrenergic receptors on the basis of publication analysis of nonclinical safety studies}

Adrenoreceptors of az-type are a separate subclass of alpha-adrenergic receptors which are localized in the central nervous system (CNS) and in almost all peripheral tissues [5]. Subtypes of $\alpha_{2} \mathrm{~A}, \alpha_{2} \mathrm{~B}, \alpha_{2} \mathrm{C}, \alpha_{2} \mathrm{D}$ are distinguished on basis of differences in their structure, distribution pattern in CNS [6] and sensitivity to pharmacological preparations [5]. Apparent interspecific differences in the ratio of subtypes of a2-AR, their density and localization in CNS are noted.

The most important subtypes of clinical significance can be considered the a2A-subtype, which is responsible for the level of wakefulness in the brain stem, and the $a_{2} \mathrm{~B}$-subtype that regulates the diameter of peripheral vessels [7].

The largest role in the implementation of interspecific differences in the effects of $\alpha_{2}$-AM is assigned to the ratio of receptor subtypes in the brain stem. For example, in the brainstem of dogs and rats $\alpha_{2} \mathrm{~A}$-subtype predominates and in the brainstem of sheep it is $a_{2} \mathrm{D}$ [8]. It should be noted that ruminants, in view of the features of $a_{2} \mathrm{~A}$ and $\alpha_{2} \mathrm{D}$ subtype functioning in the brainstem, are most sensitive to the action of a2-AM. These features should be taken into account in the prediction of the efficacy and toxicity of a2-AM based on interspecific transfer.

Sedation and analgesia caused by a2-AM depends not only on species characteristics of receptor subtypes, but also on the selectivity of the drug for the a1 or a2 subtype. The majority of well-known a2-AMs are also capable of activating the a1-subtype, this effect makes a significant contribution to the manifestations of pharmacological action, that is especially typical for low-specific agents, such as xylazine. Activation of the a1-subtype causes excitement, anxiety, an increase of locomotor activity and the level of wakefulness [9]. These effects are noted when xylazine is used in high doses: $4-8 \mathrm{mg} / \mathrm{kg}$ [10]. It was shown that stimulation of central a1-receptors reduces the hypnotic effect of a2AM, for example, dexmedetomidine [11]. It was shown that with the introduction of a2-AM in high and toxic doses at the initial period of drug action, the effects of a1-AR activation prevail [12].

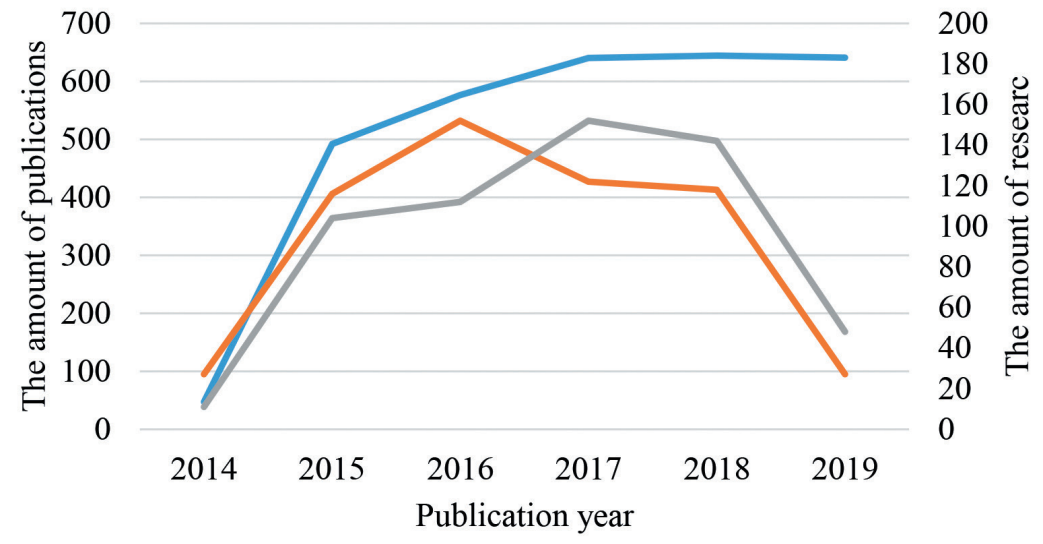

Publications $\longrightarrow$ Nonclinical trials $\longrightarrow$ Clinical trials

When used in therapeutic doses highly selective drugs possess the greatest activity and safety. It is reported that the selectivity ratio between the $a_{2} / a_{1}$ subtypes of the drugs is the following: medetomidine (1620/1), detomidine (260/1), clonidine (220/1), xylazine (160/1) [13].

\section{Sedative effect}

Figure 1 -The dynamics of publications on dexmedetomidine starting with 2014.

Рисунок 1 - Динамика публикаций по дексмедетомидину с 2014 г.

Interest in the usage of a2-AM is stipulated by their ability to cause deep sedation and anxiolytic effect. These 
effects are mediated by receptors that are predominantly localized in the neurons of the locus coeruleus of the bridge and lower part of the brainstem [10]. Activation of presynaptic a2-AM leads to blockage of the release of norepinephrine necessary to maintain the level of wakefulness. The network effect of impaired release of norepinephrine leads to sedation.

In some cases the impossibility of achieving optimal sedation with the use of a2-AM in therapeutic doses is noted. This may be due to previous stress, fear, agitation, pain and various conditions that contribute to the release of endogenous catecholamines. In clinical practice there are cases when patients were sedated with dexmedetomidine, a temporary "awakening" occurred (a decrease in the degree of depression of consciousness) as a result of exposure to external stimuli [14].

\section{Analgesia}

a2-AM cause analgesia due to stimulation of receptors at various levels of pain impulse in the spinal cord and brain [15]. Radioligand studies have shown a high concentration of a2-AR in the lateral horns of the spinal cord [16] and in the brainstem, where nociceptive stimuli are processed [17].

In the regulation of pain sensitivity there is an interaction between opioid receptors and $\alpha_{2}$-AR in the brain [18] and spinal cord [19]. a2-AR and opioid receptors are found in the same areas of the CNS and are often localized at the same neuron. It is believed that both groups of pharmacological drugs produce their analgesic effect according to similar mechanisms related to the activation of the system of secondary messengers through G-proteins, which leads to the opening of potassium channels, hyperpolarization of the postsynaptic membrane and blockade of impulse conduction along the pathways of pain sensitivity.

The results of some experimental and clinical studies indicate that the pronounced analgesic effect of a2-AM is not supported throughout the sedation period. In this regard, drugs of this pharmacological group cannot be used in the monovariant as analgesics for painful or extensive surgical interventions. The duration of the analgesic effect, as a rule, does not exceed half of the duration of the sedative one [20]. 22 -AM is recommended to use in combination with local anesthetics or other analgesics for surgical procedures. Studies of the effectiveness of a2 $A M$ in microdoses in acute and chronic pain have revealed their high activity in systemic and epidural administration [21]. However, the analgesic effect may be accompanied by undesirable sedation and negative effects on the cardiovascular system.

\section{Effects on the cardiovascular system}

By stimulating the central and peripheral adrenergic receptors, az-AMs affect the functioning of cardiovascular system. The most pronounced effect is observed in sick and weakened animals, as well as against the background of previous pathology of heart or blood vessels [22]. The main negative effect of $\alpha_{2}$ -
AM is bradycardia, bradyarrhythmia (AV blockage of 1-2 degree), a pronounced decrease in cardiac output up to $50 \%$, an increase in total peripheral vascular resistance $[23,24]$. According to the results of many studies, it was found that a decrease in cardiac output is not associated with a direct effect of a2-AM on myocardial contractility. It is secondary to an increase of total peripheral vascular resistance and a decrease in heart rate (HR) [25].

As a rule, with the introduction of a2-AM, first an increase in total peripheral vascular resistance occurs, followed by a weakening of the peripheral effect and restoration of the blood pressure (BP) level to normal values [26]. The evidence and duration of an increase in total peripheral vascular resistance and blood pressure during administration of 22 -AM depends on a number of factors: selectivity, dose, route of administration (iv or im). The initial hypertonic effect of $\alpha_{2}-\mathrm{AM}$ is more pronounced when they are administered in high doses and with intravenous method of administration compared with intramuscular one [27].

According to the analysis of many studies, it can be concluded that when using (dex)medetomidine in therapeutic doses, clinically significant hypotension does not develop. In case of blood pressure was initially elevated, then its value returns to the species norm [28].

\section{Arrhythmogenicity}

The introduction of a2-AM often causes a decrease in heart rate to $30-50 \%$ [29]. Frequent cases of vagal bradyarrhythmias, AV blockage of 1-2 degree were noted [30]. As a rule, these rhythm disturbances are not life-threatening and are associated with a reflex reaction to peripheral vasoconstriction and a decrease in sympathetic tone. With the introduction of a2-AM, an AV block of the $3 r d$ degree and a stop of the sinus node rarely occur [31]. At the same time, in an electrocardiographic study, bradycardia is not accompanied by impaired sinus rhythm [32].

Selective a2-AMs don't produce true arrhythmogenic effect (defined as a decrease in average effective dose of adrenaline for ventricular arrhythmias). In contrast, dexmedetomidine administered intramuscularly causes an increase of the effective dose of adrenaline for ventricular arrhythmias [33].

\section{Impact on the function of the respiratory system}

Sedation on the background of the introduction of a2-AM is accompanied by a decrease of frequency of respiratory rate (RR). Respiratory depression is secondary to CNS depression, however, when compared with other sedatives, the effect of a2-AM on respiration is not so pronounced even in sublethal doses [9]. In those works where the partial pressure of gases was measured, an increase in $\mathrm{pCO} 2$ was noted while maintaining a normal level of $\mathrm{pO} 2$ [34].

It has been established that the degree and clinical significance of respiratory depression increases with the use of a2-AM in combination with other sedatives. The 
most pronounced respiratory disorders were recorded after the introduction of combinations of medetomidine with opioids and propofol [35]. The combination of medetomidine with ketamine is considered to be much safer [36].

\section{Muscle relaxation}

a2-AM in analgesic doses is known to cause muscle relaxation [37]. This effect is associated with inhibition of $\alpha_{2}-\mathrm{AR}$ at the level of the spinal cord interneurons [12]. It should be noted that tizanidine is effective in reducing muscle spasticity in stroke, traumatic brain injury and multiple sclerosis due to the pronounced muscle relaxant effect [9].

\section{Hypothermia}

With sedation caused by a2-AM, a decrease in body temperature may occur. In general, a decrease in temperature under the influence of a2-AM may be associated with inhibition of CNS and a decrease in motor activity [38].

\section{Fasciculations, cramps}

This reaction develops, as a rule, in a noisy environment, on the basis of which it can be assumed that the mechanism of its occurrence is associated with an increase in sensitivity to sound stimuli [39]. In clinical practice, it is also noted that with dexmedetomidine sedation, "awakening" (increased wakefulness) is possible in patients as a response to external stimulation [40].

\section{Endocrine manifestations}

The results of various studies indicate that a2-AM reduces the level of stress hormones during surgery, and thus, can mitigate stress reactions to surgical procedures in dogs [9].

a2-AMs, especially xylazine, have been reported to increase blood glucose by suppressing insulin release and stimulating glucagon release following activation of beta and alpha pancreatic cells respectively [32]. With respect to selective a2-AM medetomidine no hyperglycemic effects were detected [20].

Intravenous administration of medetomidine in doses of $10-29 \mu \mathrm{g} / \mathrm{kg}$ induces a diuretic effect lasting up to 4 hours [41].

An increase of the release of growth hormone under the influence of a2-AM was revealed, however, the clinical significance of this effect has not been conclusively established [3]

\section{Vomiting}

a2-AM induces vomiting in animals due to stimulation of chemoreceptors of the trigger zone located in the locus coeruleus region of the brain [42]. Xylazine induces vomiting at the initial period of sedation [43].

According to clinical safety studies of dexmedetomidine in healthy volunteers, vomiting in humans following the administration of the drug develops in $4-6 \%$ of cases, depending on the route of administration [4].

\section{Effect on the digestive tract}

a2-AM reduces gastric secretion, increases the duration of food transit [9], and inhibits colon motility [44].

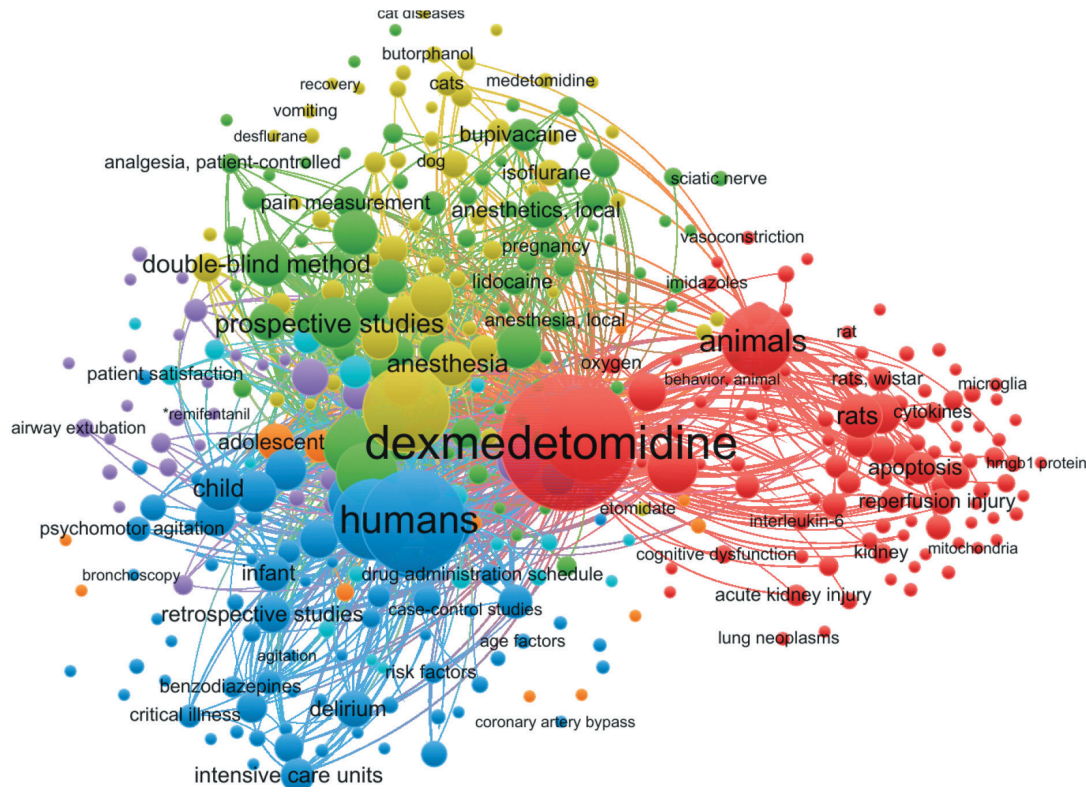

\section{Intraocular pressure}

The multidirectional effect of az-AM on pupil diameter and intraocular pressure in animals of various species has been reported [45].

\section{Intracranial pressure}

a2-AM reduces central blood flow due to vasoconstriction, and thus reduces intracranial pressure in dogs anesthetized with isoflurane on mechanical ventilation [46].

The analysis of pharmacodynamics effects of central a2AM allows to assume a wide possibility of application of drugs belonging to this group in clinical practice both in a monovariant and in combination with other drugs. Moreover, therapeutic indications for the use of central a2-AMs are not limited only to use in anesthesiology, which requires a number of additional studies of their effectiveness and safety in the experiment.

\section{The analysis of trends and directions of research of a2-am-adrenomimetics with the example of dexmedetomidine}

To determine the trends and directions of research of central a2-AM the most frequently used drug in clinical practice, dexmedetomidine, was chosen. The analysis used bibliographic data selected in the MEDLINE database
Figure 2 - Map of the occurrence of keywords and MESH terms in publications devoted to dexmedetomidine 2014-2019, $\mathrm{n}=3040$

Figure 2 - Map of the occurrence of keywords and MESH terms in publications devoted to dexmedetomidine 2014-2019, $\mathrm{n}=3040$ 
for the keyword "dexmedetomidine" with a temporary filter of " 5 years". The selected array of information was analyzed using text-mining technology using the graphic visualization method in VOSviewer version 1.6.11 (Center for Science and Technology Research (CWTS) of the University of Leiden, the Netherlands). At the first stage of the study, a conceptual map was constructed based on the frequency of occurrence of keywords and MESHterms (Figure 2).

The analysis, based on indicators of the relationship between the terms, identified 4 main clusters (in the figure they are presented in different colors). The main directions of research on $\mathrm{az}_{2}-\mathrm{AM}$ are related to the experimental study of the cytoprotective effect of dexmedetomidine on models of damage of different organs and systems, with clinical safety studies in anesthesiology practice, with application in veterinary medicine. To clarify the results, an in-depth bibliographic

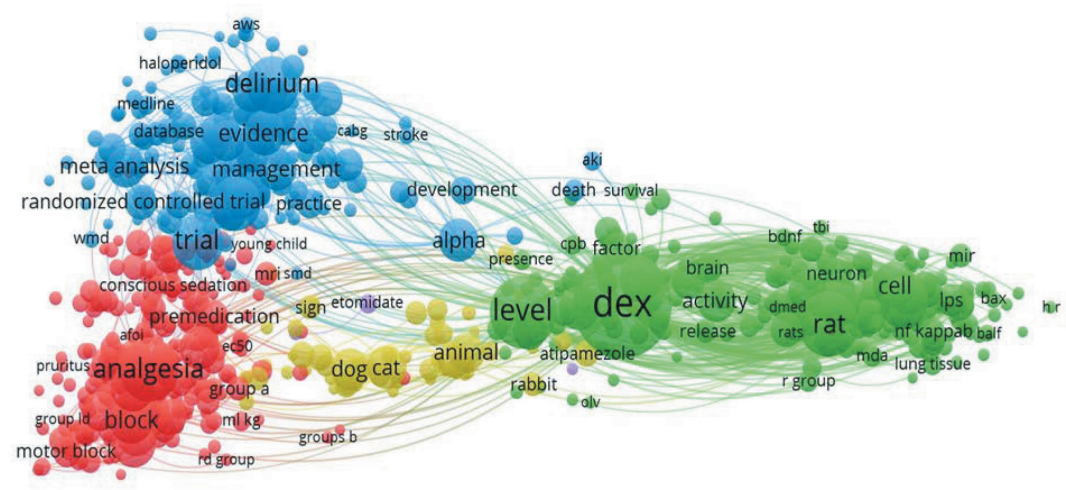

Figure 3 - Map of the frequency of occurrence of the main terms and definitions in the texts of publications on dexmedetomidine 2014-2019, $\mathrm{n}=3040$

Рисунок 3 - Карта частоты встречаемости основных терминов и определений в текстах публикаций по дексмедетомидину 2014-2019, $\mathrm{n}=3040$ analysis of the published materials was carried out, including the full text of the articles (Figure 3).

The presented map made it possible to identify more clearly the main areas of research in the field of a2-AM studies. As the most promising area of research the use of a2-AM cytoprotectors and antioxidants should be considered. The effects of the protective effect on alveolocytes [47], cardiomyocytes [48, 49], hepatocytes [50] are described in details in literature. To date, the mechanisms of such action are at the initial stage of their study. It is knownabout the reduction of lipid peroxidation products, the production of peroxynitrile radicals [51], the stimulation of the activity of endogenous glutathione and superoxide dismutase [52]. A significant role in this

\section{REFERENCES}

1. Giovannitti J, Thoms S, Crawford J. Alpha-2 Adrenergic Receptor Agonists: A Review of Current Clinical Applications. Anesth Prog. 2015;62(1):31-38. doi:10.2344/0003-3006-62.1.31

2. Lamont LA, Burton SA, Caines D, Troncy ED. Effects of 2 different infusion rates of medetomidine on sedation score, cardiopulmonary parameters, and serum levels case is given to stabilization of the inner mitochondrial membranes $[53,54]$. In our opinion, under the conditions of modeling damage of various types, accompanied by depletion of the antioxidant systems of the body, an increase in the effectiveness of dexmedetomidine can be achieved by restoring the pool of water-soluble cytosolic antioxidants.

Another important block of research is the study of the combined effect of a2-AM with drugs of other pharmacological groups [55], which to a greater extent potentiate the analgesic or anesthetic effect of each other. These studies are naturally associated with clinical trials with various groups of people $[56,57,58]$.

Separatestudies are devoted to the research of combined application of agonists and antagonists of a2-AM [55]. In these publications, the authors set themselves a goal to stop possible side and undesirable effects, as well as to achieve more controlled sedation.

Based on the analysis, we can formulate several of the most promising trends and directions in the study of central az-AM, which determine the expansion of indications for their future application in medicobiological research:

1. The study of the effects and mechanisms of cytoprotective and antioxidant effects, including their combined administration with non-enzymatic antioxidants. The effects associated with stabilization of the inner mitochondrial membrane are of particular interest.

2. The study of combinations of painkillers intended for application in self-help and mutual assistance, as well as first aid.

3. The study of its own anesthetic effect in a monovariant. In this case, it will be extremely important to conduct in-depth experiments to assess safety during the administration of drugs in sublethal doses, as well as to assess changes in the functioning of external respiration and indicators of the cardiovascular system.

4. The study of drug combinations containing central $\alpha_{2}-$ AM antagonists (for example, atipamezole) with delayed controlled release in order to stop possible side and undesirable effects.

of medetomidine in healthy dogs. Can J Vet Res. 2012;76(4):308-316.

3. Zhang Z, Ferretti V, Güntan I, et al. Neuronal ensembles sufficient for recovery sleep and the sedative actions of a2 adrenergic agonists. Nat Neurosci. 2015;18(4):553561. doi:10.1038/nn.3957

4. Weerink MAS, Struys MMRF, Hannivoort LN, Barends CRM, Absalom AR, Colin P. Clinical Pharmacokinetics 
and Pharmacodynamics of Dexmedetomidine. Clin Pharmacokinet. 2017;56(8):893-913. doi:10.1007/ S40262-017-0507-7

5. Mannelli L, Micheli L, Crocetti L, et al. a2 Adrenoceptor: a Target for Neuropathic Pain Treatment. Mini reviews in medicinal chemistry. Mini Rev Med Chem. 2017;17(2):95107. doi:10.2174/1389557516666160609065535. (2016).

6. Ostopovici-Halip L, Curpăn R, Mracec M, Bologa CG. Structural determinants of the alphaz adrenoceptor subtype selectivity. J Mol Graph Model. 2011;29(8):10301038. doi:10.1016/j.jmgm.2011.04.011

7. Fukuda M, Vazquez AL, Zong X, Kim SG. Effects of the $a_{2}$-adrenergic receptor agonist dexmedetomidine on neural, vascular and BOLD $F M R I$ responses in the somatosensory cortex. Eur J Neurosci. 2013;37(1):80-95. doi:10.1111/ejn.12024

8. Gyires K, Zádori Z, Török T, Mátyus P. a2Adrenoceptor subtypes-mediated physiological, pharmacological actions. Neurochemistry International. 2009 dec.;55(7):447-453. https://doi.org/10.1016/j. neuint.2009.05.014

9. Sinclair MD. A review of the physiological effects of alphaz-agonists related to the clinical use of medetomidine in small animal practice. Can Vet J. 2003;44(11):885-897.

10. Funai $Y$, Pickering $A E$, Uta $D$, et al. Systemic dexmedetomidine augments inhibitory synaptic transmission in the superficial dorsal horn through activation of descending noradrenergic control: an in vivo patch-clamp analysis of analgesic mechanisms. Pain. 2014;155(3):617-628. doi:10.1016/j.pain.2013.12.018

11. Naaz S, Ozair E. Dexmedetomidine in current anaesthesia practice- a review. J Clin Diagn Res. 2014;8(10):GE01-GE4. doi:10.7860/JCDR/2014/9624.4946

12. Sharma S, Jain P. Dexmedetomidine and Anesthesia. Indian Journal of Clinical Practice. 2013;24(3):223-225.

13. Shah Z, Ding M. A Review on the Current Use of Alpha2 Agonists in Small Ruminants. Kafkas Universitesi Veteriner Fakultesi Dergisi. 2014;20(4):633-639. doi:10.9775/kvfd.2013.10541

14. Ozaki M, Takeda J, Tanaka K, et al. Safety and efficacy of dexmedetomidine for long-term sedation in critically ill patients. J Anesth. 2014;28(1):38-50. doi:10.1007/ s00540-013-1678-5

15. Thomas B, Bantel C, Stone L, Wilcox GL. Alpha(a) 2-Adrenergic Agonists in Pain Treatment. In: Gebhart GF, Schmidt RF (eds) Encyclopedia of Pain. Springer, Berlin, Heidelberg; 2013. p.79-86.

16. Ferdousi M. Structure-Affinity Relationship Study of Novel Imidazoline Ligands at Imidazoline Binding Sites and $\alpha$-Adrenoceptors [A thesis submitted in partial fulfillment of the requirements for the degree of Master of Science]. Department of Pharmacology, University of Alberta; 2014.

17. Bell A. The neurobiology of acute pain. Vet J. 2018;(237):55-62. doi:10.1016/j.tvjl.2018.05.004

18. Root-Bernstein R, Turke M, Subhramanyam UKT, Churchill B, Labahn J. Adrenergic Agonists Bind to Adrenergic-Receptor-Like Regions of the Mu Opioid Receptor, Enhancing Morphine and MethionineEnkephalin Binding: A New Approach to «Biased Opioids»?. Int J Mol Sci. 2018;19(1):272. doi:10.3390/ ijms19010272

19. Chabot-Doré AJ, Schuster DJ, Stone LS, Wilcox $\mathrm{GL}$. Analgesic synergy between opioid and a2 -adrenoceptors. Br J Pharmacol. 2015;172(2):388-402. doi:10.1111/bph.12695

20. Kaur M, Singh PM. Current role of dexmedetomidine in clinical anesthesia and intensive care. Anesth Essays Res. 2011;5(2):128-133. doi:10.4103/0259-1162.94750

21. Bajwa SJ, Bajwa SK, Kaur J, et al. Dexmedetomidine and clonidine in epidural anaesthesia: A comparative evaluation. Indian J Anaesth. 2011;55(2):116-121. doi:10.4103/0019-5049.79883

22. Baumgartner C, Bollerhey M, Ebner J, Schuster T, Henke J, Erhardt W. Effects of medetomidinemidazolam-fentanyl IV bolus injections and its reversal by specific antagonists on cardiovascular function in rabbits. Can J Vet Res. 2010;74(4):286-298

23. Egger CM, Love L, Doherty T. Pain Management in Veterinary Practice. Wiley Blackwell, Chichester, UK, 2013. 464 p.

24. Murrell JC, Hellebrekers $\sqcup$. Medetomidine and dexmedetomidine: a review of cardiovascular effects and antinociceptive properties in the dog. Veterinary Anaesthesia and Analgesia. 2005;32(3):117-127. doi:10.1111/ j.1467-2995.2005.00233.x

25. Adam M, Raekallio MR, Salla KM, et al. Effects of the peripherally acting az-adrenoceptor antagonist MK-467 on cardiopulmonary function in sheep sedated by intramuscular administration of medetomidine and ketamine and reversed by intramuscular administration of atipamezole. Am J Vet Res. 2018;79(9):921-932. doi:10.246o/ajvr.79.9.921

26. Ingersoll-Weng E, Manecke GJ, Thistlethwaite PA. Dexmedetomidine and cardiac arrest. Anesthesiology. 2004;100(3):738-9. doi:10.1097/00000542-20040300000040

27. Page RL, O'Bryant CL, Cheng D, et al. Drugs That May Cause or Exacerbate Heart Failure: A Scientific Statement From the American Heart Association. Circulation. 2016;134(6):e32-69. doi:10.1161/CIR.0000000000000426

28. Carter JE, Campbell NB, Posner LP, Swanson C. The hemodynamic effects of medetomidine continuous rate 
infusions in the dog. Vet Anaesth Analg. 2010;37(3):197206. doi:10.1111/j.1467-2995.2009.00522.x

29. Nelson W, Couto CG. Small Animal Internal Medicine. St. Louis, MO: Elsevier/Mosby; 2015. 1473 p.

30. Kaartinen MJ, Cuvelliez S, Brouillard L, Rondenay Y, Kona-Boun JJ, Troncy E. Survey of utilization of medetomidine and atipamezole in private veterinary practice in Quebec in 2002. Can Vet J. 2007;48(7):725-730.

31. Wu J, Lei E, Zhou J, Zhao D. Impacts and mechanisms of dexmedetomidine $\mathrm{HCl}$ on heart rate in rabbit with bilateral vagotomy or sympathectomy. Biomedical Research. 2017;28(17):7509-7513.

32. Yaygingül $R$, Belge $A$. The comparison of clinical and cardiopulmonary effects of xylazine, medetomidine and detomidine in dogs. Ankara Üniv. Vet. Fak. Derg. 2018;65:313-322.

33. Berg T. $\beta$ - and a2-Adrenoceptor Control of Vascular Tension and Catecholamine Release in Female Normotensive and Spontaneously Hypertensive Rats. Front Neurol. 2017;8:130. doi:10.3389/fneur.2017.00130

34. Chittick E, Horne W, Wolfe B, Sladky K. Cardiopulmonary assessment of medetomidine, ketamine, and butorphanol anesthesia in captive Thomson's gazelles (Gazella thomsoni). J Zoo Wildl Med. 2001;32(2):168-75. doi:10.1638/10427260(2001)032[0168:CAOMKA]2.0.CO;2

35. Raillard M, Michaut-Castrillo J, Spreux D, et al. Comparison of medetomidine-morphine and medetomidine-methadone for sedation, isoflurane requirement and postoperative analgesia in dogs undergoing laparoscopy. Vet Anaesth Analg. 2017;44(1):17-27. doi:10.1111/vaa.12394.

36. Muller LI, Osborn DA, Doherty T. Optimal medetomidine dose when combined with ketamine and tiletamine-zolazepam to immobilize white-tailed deer. J Wildl Dis. 2012;48(2):477- 482.

37. Rauser P, Zatloukal J, Neâas A, et al. Combined Medetomidine and Ketamine for Short-term Anaesthesia in Ferrets - A Clinical Study. Acta Veterinaria Brno. 2012;71(2):243- 248. doi:10.2754/avb200271020243

38. Schmitz S, Tacke S, Guth B, Henke J. Repeated anaesthesia with isoflurane and medetomidinemidazolam-fentanyl in guinea pigs and its influence on physiological parameters. PLoSOne. 2017;12(3):e0174423. doi:10.1371/journal.pone.0174423

39. Le Chevallier D, Slingsby L, Murrell J. Use of midazolam in combination with medetomidine for premedication in healthy dogs. Vet Anaesth Analg. 2019;46(1):74-78. doi:10.1016/j.vaa.2018.08.001

40. Shukry M, Miller JA. Update on dexmedetomidine: use in nonintubated patients requiring sedation for surgical procedures. Ther Clin Risk Manag. 2010;6:111-121 p. doi:10.2147/tcrm.s5374

41. Scott-Warren VL, Sebastian J. Dexmedetomidine: its use in intensive care medicine and anaesthesia. BJA Education. 2016;16(7), 242-246 p. doi:10.1093/bjaed/ mkv047

42. Taylor BK, Westlund KN. The noradrenergic locus coeruleus as a chronic pain generator. J Neurosci Res. 2017;95(6):1336-1346. doi:10.1002/jnr.23956

43. Cassu RN, Melchert A, Canoa JT, Martins PD. Sedative and clinical effects of the pharmacopuncture with xylazine in dogs. Acta Cir Bras. 2014;29(1):47-52. doi:10.1590/S0102-86502014000100007

44. Kallio-Kujala IJ, Turunen HA, Raekallio MR, et al. Peripherally acting $\alpha$-adrenoceptor antagonist MK-467 with intramuscular medetomidine and butorphanol in dogs: A prospective, randomised, clinical trial. Vet J. 2018;240:22-26. doi:10.1016/j.tvjl.2018.08.007

45. Kanda T, Iguchi A, Yoshioka C, et al. Effects of medetomidine and xylazine on intraocular pressure and pupil size in healthy Beagle dogs. Vet Anaesth Analg. 2015;42(6):623-8. doi:10.1111/vaa.12249

46. Keegan RD, Greene SA, et al. Effects of medetomidine administration on intracranial pressure and cardiovascular variables of isoflurane-anesthetized dogs. Am J Vet Res. 1995;56(2):193-198.

47. Cao G, Zhang E. [Protective effects of dexmedetomidine against pulmonary ischemiareperfusion injury during cardiopulmonary bypass in rats]. [Article in Chinese].Nan Fang Yi Ke Da Xue Xue Bao. 2019;39(8):980-986. doi: 10.12122/j.issn.16734254.2019.08.16.

48. He L, Hao S, Wang Y, et al. Dexmedetomidine preconditioning attenuates ischemia/reperfusion injury in isolated rat hearts with endothelial dysfunction. Biomed Pharmacother. 2019;53(2):74-81. doi: 10.1016/j. biopha.2019.108837.

49. Cheng $\mathrm{X}, \mathrm{Hu} J$, Wang $\mathrm{Y}$, et al. Effects of Dexmedetomidine Postconditioning on Myocardial Ischemia/Reperfusion Injury in Diabetic Rats: Role of the PI3K/Akt-Dependent Signaling Pathway. J Diabetes Res. 2018;2018:3071959. doi:10.1155/2018/3071959

50. Sha J, Zhang H, Zhao Y, et al. Dexmedetomidine attenuates lipopolysaccharide-induced liver oxidative stress and cell apoptosis in rats by increasing GSK-3B/ MKP-1/Nrf2 pathway activity via the a2 adrenergic receptor. Toxicol Appl Pharmacol. 2019;1;364:144-152. doi: 10.1016/j.taap.2018.12.017.

51. Chen Y, Luan L, Wang C, et al. Dexmedetomidine protects against lipopolysaccharide-induced early acute kidney injury by inhibiting the iNOS/NO signaling pathway in rats. Nitric Oxide. 2019;1;85:1-9. doi: 10.1016/j. niox.2019.01.009. 
52. Sha J, Zhang H, Zhao Y, et al. Dexmedetomidine attenuates lipopolysaccharide-induced liver oxidative stress and cell apoptosis in rats by increasing GSK-3 $\beta /$ MKP-1/Nrf2 pathway activity via the a2 adrenergic receptor. Toxicol Appl Pharmacol. 2019;364:144-152. doi: 10.1016/j.taap.2018.12.017.

53. Li F, Wang X, Deng Z, et al. Dexmedetomidine reduces oxidative stress and provides neuroprotection in a model of traumatic brain injury via the PGC-1a signaling pathway. Neuropeptides. 2018;72:58-64. doi: 10.1016/j. npep.2018.10.004.

54. Chen Y, Feng X, Hu X, et al. Dexmedetomidine Ameliorates Acute Stress-Induced Kidney Injury by Attenuating Oxidative Stress and Apoptosis through Inhibition of the ROS/JNK Signaling Pathway. Oxid Med Cell Longev. 2018:4035310. doi:10.1155/2018/4035310

55. Kallio-Kujala IJ, Bennett RC, Raekallio MR, et al. Effects of dexmedetomidine and MK-467 on plasma glucose, insulin and glucagon in a glibenclamide-induced canine hypoglycaemia model. Vet J. 2018;242:33-38. doi: 10.1016/j.tvjl.2018.09.012

56. Beloeil H, Laviolle B, Menard C, et al. POFA trial study protocol: a multicentre, double-blind, randomised, controlled clinical trial comparing opioid-free versus opioid anaesthesia on postoperative opioid-related adverse events after major or intermediate non-cardiac surgery. BMJ Open. 2018;8(6):e020873. doi:10.1136/ bmjopen-2017-020873

57. Shankar P, Mueller A, Packiasabapathy S, et al. Dexmedetomidine and intravenous acetaminophen for the prevention of postoperative delirium following cardiac surgery (DEXACET trial): protocol for a prospective randomized controlled trial. Trials. 2018;19(1):326. doi:10.1186/s13063-018-2718-0

58. Louis C, Godet T, Chanques G, et al. Effects of dexmedetomidine on delirium duration of non-intubated ICU patients (4D trial): study protocol for a randomized trial. Trials. 2018;19(1):307. doi:10.1186/s13063-018-2656-x

\section{Author information}

Nikolay G. Vengerovich - MD, PhD in Medicine, Deputy head of scientific Department, State Scientific Test Research Institute of Military Medicine, Ministry of Defense of the Russian Federation, Saint-Petersburg, Russia; e-mail: gniiivm-2@mail.ru

Igor M. Ivanov - PhD in Medicine, Deputy head of scientific Department, State Scientific Test Research Institute of Military Medicine, Ministry of Defense of the Russian Federation, Saint-Petersburg, Russia; e-mail: igor611ivanov@gmail.com

Yulia A. Proshina - Research Officer, State Scientific Test Research Institute of Military Medicine, Ministry of Defense of the Russian Federation, Saint-Petersburg, Russia; e-mail: proshinayulia@yandex.ru

\section{Информация об авторах}

Николай Григорьевич Венгерович - д-р мед. наук, заместитель начальника научного отдела, Государственный научно-исследовательский испытательный институт военной медицины Министерства обороны Российской Федерации, Санкт-Петербург, Россия; e-mail: gniiivm-2@mail.ru

Игорь Михайлович Иванов - канд. мед. наук, заместитель начальника научного отдела, Государственный научно-исследовательский испытательный институт военной медицины Министерства обороны Российской Федерации, Санкт-Петербург, Россия; e-mail: igorb17ivanov@gmail.com

Юлия Александровна Прошина - научный сотрудник, Государственный научноисследовательский испытательный институт военной медицины Министерства обороны Российской Федерации, Санкт-Петербург, Россия; e-mail: proshinayulia@yandex.ru 